\title{
The Impact of Emotional Intelligence on Readiness for Organizational Change: A Case Study on a Government Authority in Saudi Arabia
}

\author{
Mohammed Saud Alzahrani \\ College of Business Administration, Al Baha University, Al Baha, KSA \\ Email: msoudalzahrani@bu.edu.sa
}

How to cite this paper: Alzahrani, M.S. (2019) The Impact of Emotional Intelligence on Readiness for Organizational Change: A Case Study on a Government Authority in Saudi Arabia. American Journal of Industrial and Business Management, 9, 1880-1889. https://doi.org/10.4236/ajibm.2019.99121

Received: August 18, 2019

Accepted: September 16, 2019

Published: September 19, 2019

Copyright () 2019 by author(s) and Scientific Research Publishing Inc. This work is licensed under the Creative Commons Attribution International License (CC BY 4.0).

http://creativecommons.org/licenses/by/4.0/

(c) (i) Open Access

\begin{abstract}
This study sought mainly to examine the effect of Emotional intelligence (EI) and readiness for organizational change (RFC). Additionally, the study sought to explore the association between EI, RFC and demographic variables. The data were collected from employees from a government authority in Jeddah city, Saudi Arabia. The data were analyzed using Spearman's rho to find the relation between EI and employee's RFC. Then, Simple Linear Regression was applied to find the effect of EI on the employee's RFC. In addition, association between RFC and demographic variables was determined by Chi-square. The findings of this study confirmed the significant relationship between EI and employees' readiness to accept change. There was a statistically significant association between RFC and education level among participants. However, there was no association between other demographic variables and RFC or EI. This study has some limitations that were presented at the end of the study.
\end{abstract}

\section{Keywords}

Emotional Intelligence, Individual Readiness for Change, Organizational Change

\section{Introduction}

Change is a constant process that disrupts the typical patterns and frameworks of organizations. Therefore, organizations usually strive to evolve rapidly to adapt to new changes and remain competitive. Nonetheless many researchers posited that about $70 \%$ of change initiatives do not yield the intended outcome. 
This failure is attributed mostly to the individuals' ability to deal with change challenges. [1] contended that individuals' readiness for change is a fundamental prerequisite for success in organizational change. The success of organizational change is reliant on the individuals' positive perceptions and feelings about change, and consequently compels individuals to embrace and support change.

Individual readiness for change, which hereafter will be identified as RFC, has been defined as an individual's "beliefs, attitudes, and intentions regarding the extent to which changes are needed and the organization's capacity to successfully undertake those changes" ([2] p. 681). Researchers of earlier works have adduced the role of readiness in the effective implementation of change [3] [4] [5].

Utilizing previous observations, researchers have focused on factors that may have influenced employees' readiness for organizational change (RFC). Several studies have identified Emotional Intelligence (hereafter will be identified as EI) as a significant construct that has had an impact on change [6] [7] [8], specifically, the contribution of EI to readiness for organizational change [9] [10].

Studies examining the role of EI in fostering employees' RFC are limited, especially in Saudi Arabian context. In this paper I proposed that EI would promote readiness for organizational change. The primary question of this study is as follows: Is there any significant positive relationship between EI and RFC?

\section{Literature Review}

\subsection{Individual Readiness for Change}

[11] noted the importance of reframing the problem of change from resistance to change to readiness for change (RFC). They argued that, "using the term readiness instead of resistance is more congruent with the roles that the coaches and champions play in introducing change" ([11] p. 132). Organizations need to focus on the employees since they constitute the engine for driving change into its right destination. To be successful, organizational change initiatives must be supported, adopted and implemented effectively by employees [12] [13] [14]. Therefore, individuals' readiness is salient for the failure success of organizational change [11] [15].

Individual readiness for organizational change has been defined severally; for example, [16] defined RFC as, "the extent to which an individual or individuals are cognitively and emotionally inclined to accept, embrace and adopt a particular plan to purposefully alter the status quo" ([17] p. 235). While [2] defined RFC as the individual's cognitive assessment that makes him either embrace or oppose any change initiative. Regardless of the variations in the conceptualization of individual readiness, the consensus is that individual RFC requires an individual's belief that change is necessary, applicable and can bring about positive outcomes [5] [16] [17].

Ample individual RFC has proven to be a critical antecedent to the successful 
implementation of changes [18]. A study conducted by [15] revealed that employees with a higher level of readiness in the early stage of change implementation showed more willingness to adjust their behaviors to support the change initiative.

[19] stated that change programs failed due to lack of the necessary psychological preparation and support for individuals which paralyzes the organizations embarking on change initiatives. The significance of individual's readiness for change has been compelling for organizations to further work on preparing employees and focus on individual change management.

Many researchers examined the factors that predict individual RFC in order to provide more understanding of this phenomenon.

Studies [5] [15] [16] [18] concluded that individual RFC was influenced by an array of factors such as social relations in the workplace, organizational commitment, flexible policies and procedures, emotional exhaustion and depression, personal resilience, affective commitment, and general attitude [4] [15] [16] [20].

\subsection{Emotional Intelligence}

The origins of EI date back to [21] social intelligence refers the ability to identify and manage relations with others. However, the first formal model of EI was developed by [22]. Their model became known as the "ability" model and comprised of three areas; appraisal and expression of emotion, regulation of emotion, and utilization of emotion as intelligence.

The concept of EI gained popularity when [7] published his book, "Emotional Intelligence", and has been the most influential of the scientific conceptualization of EI.

The research of [22] [23] have inspired, shaped and guided subsequent frameworks and conceptualizations of EI. The theoretical framework of EI as an ability was posited by [24] as a set of skills and personal competencies. Furthermore, EI is defined as "the ability to monitor one's own and others' feelings and emotions, to discriminate among them and to use this information to guide one's thinking and action" ([22], p. 189). Additionally, [17] conceptualized EI as comprising a set of abilities that may be utilized to understand the individual's own as well as other's emotions, and to think and behave rationally. On the other hand, [23] perceived EI as set of learned skills and competencies. Many studies emphasized the impact of EI on some organizational outcomes as, employee effectiveness, performance, transformational leadership, leadership capacity, career commitment, managerial advancement, and organizational change [25] [26] [27]. Earlier researchers have confirmed the significance of EI in dealing with change [23] [24]. This argument was advanced by other researchers. For example, [8] found that EI contributed to the individual's adaptation and facilitate revolutionary change process. In another study by [6] the results showed that individuals with high EI can cope with workplace stresses that might occur as a consequence of organizational change. 
A study conducted by [9] was designed to examine the relationships of EI, organizational commitment, and leadership behavior as influences on organization RFC in a higher education institution; concluded that RFC was affected by EI, organizational commitment and transactional leadership behavior. A recent study conducted by [28] examined the effects of leadership behavior and EI on RFC among employees in public institutions of higher education in Malaysia found, among other findings, that EI had a significant effect on employees' RFC. [10] investigated the relationship of EI with the cultural quotient (CQ) using a population sample of 109 mid-level managers in the public sector. The results found that Emotional Quotient (EQ) had significantly positive relationship with change readiness $(r=0.513)$ and the subscales of change readiness were also positively related with EQ.

Based on the previous discussion, the following hypothesis was developed:

$\mathrm{H} 1$ : Emotional Intelligence (EI) is positively associated with employee's readiness for change.

\section{Research Methodology}

This study adopted a quantitative approach to examine the hypothesis. The sample population was selected from employees of a government authority in Jeddah city, Saudi Arabia. Using the random sampling technique, an online survey was emailed to 200 employees. Of the 200 surveys emailed, 67 employees responded to the surveys; $64.2 \%$ males and $61.2 \%$ females.

\section{Instruments}

The self-reported EI scale was used to assess the EI of the participants. This scale was developed by [29] comprises 33 items. The respondents were asked to indicate the degree to which they agreed with the statements on a scale of 1 -strongly disagree to 7-strongly agree. The employee readiness questionnaire consisted of 14 items, this tool was developed by [20].

\section{Data Analysis}

The collected data were analyzed using SPSS v. 23 program: "Statistical Package for Social Sciences". Firstly, Cronbach's alpha was utilized to determine the reliability for the questionnaire. Secondly, Spearman's rho was used to find the relation between EI and employee's RFC. Thirdly, Simple Linear Regression was applied to find the effect of EI on the employee's RFC. Finally, Chi square was used to test the relation between the level of EI, employees' RFC and the demographic variables.

\subsection{Reliability}

Table 1 shows that Cronbach's Alpha was 0.894 for the whole questionnaire, 0.884 for the EI and 0.856 for the RFC. Therefore the questionnaire was reliable because the recommended cutoff is 0.70 according to experts such as [30] (Table $1)$. 
Table 1. Reliability result.

\begin{tabular}{ccc}
\hline Dimensions & N of Items & Cronbach's Alpha Value \\
\hline Emotional Intelligence (EI) & 33 & 0.884 \\
Readiness for change (RFC) & 14 & 0.856 \\
Overall & 47 & 0.894 \\
\hline
\end{tabular}

\subsection{Result}

The current study examined the level of EI and its effect on employee's RFC. Descriptive statistics were used to analyze the data of EI (minimum, maximum, mean and Standard Deviation). The overall mean score was 3.7897 with a St.Dev of 0.39651 , which is considered a high level in 5 point Likert Scale; since mean score $\geq 3.40$ (Table 2).

Descriptive statistics for Readiness for change show that overall mean score for Readiness for change was 5.6034 with a St.Dev of 0.78486 , which considered a high level of agreements in 5-point Likert Scale; since mean score $\geq 3.40$ (Table 3).

Spearman's rho test was performed to test the association between demographic variables and EI. Emotional intelligence was classified into two levels, low and high. The low level for mean score $<4$ which found for $(\mathrm{N}=47,70.1 \%)$, and the high level had mean score $\geq 4$ which found for ( $N=20,29.9 \%)$. Likewise, RFC was classified into two levels, low and high; where low level had mean score $<5$ which found for $(\mathrm{N}=11,16.4 \%)$, and high level for mean score $\geq 5$ which found for $(\mathrm{N}=56,83.6 \%)$.

Each participant with high level in EI, where $\mathrm{N}=18,26.9 \%$ had high level in RFC, except two participants. However, 38, 56.7\% with low level of EI had high level of RFC. Spearman's rho value was found to be 0.330 with P-value of $0.006<$ 0.05 , indicated moderately association between levels of EI and RFC (Table 4).

Simple Linear Regression was utilized in which the dependent variable was RFC and the independent variable was EI. The result shows that the model was significant with the $\mathrm{P}$-value $<0.05$, and $\mathrm{R}=0.356$ and $\mathrm{R}$-square $=0.127$; meaning EI showed $13 \%$ of the variation in the dependent variable (RFC).

Absence of multicollinearity was checked by conducting correlations among the dependent variables. Each pair of dependent variables were found moderately related without any correlation over 0.80 , concluded no multicollinearity among variables $(\mathrm{VIF}<3)$. Also assumption for normality for the residual was met. F-ANOVA had P-value less than 0.05 indicate significant model; such independent variables explained variation in the dependent variable. Regression coefficient Beta for EI was 0.704 with $(\mathrm{P}<0.05)$, indicate that for every increase in EI, predictor variable, by one scale unit, the RFC, dependent variable, will increase by 0.704 unit (Table 5).

Association between RFC and demographic variables was determined by Chi-square test which showed that there was a statistically significant association between RFC and education level among participants $(P<0.05)$. Participants 
Table 2. Descriptive statistics of emotional intelligence $(\mathrm{N}=67)$.

\begin{tabular}{|c|c|c|c|c|}
\hline Phrases & Min & Max & Mean & Std. Dev \\
\hline 1) I know when to speak about my personal problems to others. & 1.00 & 5.00 & 4.0000 & 0.96922 \\
\hline $\begin{array}{l}\text { 2) When I am faced with obstacles, I remember times I faced similar obstacles and } \\
\text { overcame them. }\end{array}$ & 1.00 & 5.00 & 4.0149 & 0.94536 \\
\hline 3) I expect that I will do well on most things I try. & 1.00 & 5.00 & 4.1493 & 0.82119 \\
\hline 4) Other people find it easy to confide in me. & 1.00 & 5.00 & 3.7313 & 0.88046 \\
\hline 5) I find it hard to understand the non-verbal messages of other people. & 1.00 & 5.00 & 2.5672 & 0.97272 \\
\hline $\begin{array}{l}\text { 6) Some of the major events of my life have led me to re-evaluate what is important and not } \\
\text { important. }\end{array}$ & 2.00 & 5.00 & 4.2239 & 0.77501 \\
\hline 7) When my mood changes, I see new possibilities. & 1.00 & 5.00 & 3.6866 & 1.07603 \\
\hline 8) Emotions are one of the things that make my life worth living. & 1.00 & 5.00 & 3.7015 & 1.11484 \\
\hline 9) I am aware of my emotions as I experience them. & 1.00 & 5.00 & 3.8806 & 0.91324 \\
\hline 10) I expect good things to happen. & 1.00 & 5.00 & 4.0299 & 0.88712 \\
\hline 11) I like to share my emotions with others. & 1.00 & 5.00 & 3.4328 & 0.97272 \\
\hline 12) When I experience a positive emotion, I know how to make it last. & 1.00 & 5.00 & 3.4030 & 0.98565 \\
\hline 13) I arrange events others enjoy. & 1.00 & 5.00 & 3.6269 & 0.90178 \\
\hline 14) I seek out activities that make me happy. & 1.00 & 5.00 & 4.0597 & 0.83268 \\
\hline 15) I am aware of the non-verbal messages I send to others. & 1.00 & 5.00 & 3.5970 & 1.01593 \\
\hline 16) I present myself in a way that makes a good impression on others. & 2.00 & 5.00 & 4.0299 & 0.73794 \\
\hline 17) When I am in a positive mood, solving problems is easy for me. & 2.00 & 5.00 & 4.2537 & 0.72495 \\
\hline 18. By looking at their facial expressions, I recognize the emotions people are experiencing. & 2.00 & 5.00 & 4.1493 & 0.63374 \\
\hline 19) I know why my emotions change. & 2.00 & 5.00 & 3.9851 & 0.61527 \\
\hline 20) When I am in a positive mood, I am able to come up with new ideas. & 2.00 & 5.00 & 4.4030 & 0.60452 \\
\hline 21) I have control over my emotions. & 2.00 & 5.00 & 3.7612 & 0.79942 \\
\hline 22) I easily recognize my emotions as I experience them. & 2.00 & 5.00 & 4.0149 & 0.63943 \\
\hline 23) I motivate myself by imagining a good outcome to tasks I take on. & 2.00 & 5.00 & 3.9552 & 0.78688 \\
\hline 24) I compliment others when they have done something well. & 2.00 & 5.00 & 4.2239 & 0.67016 \\
\hline 25) I am aware of the non-verbal messages other people send. & 2.00 & 5.00 & 3.8060 & 0.74343 \\
\hline $\begin{array}{l}\text { 26) When another person tells me about an important event in his or her life, I almost feel } \\
\text { as though I have experienced this event myself. }\end{array}$ & 2.00 & 5.00 & 3.7463 & 0.74556 \\
\hline 27) When I feel a change in emotions, I tend to come up with new ideas. & 2.00 & 5.00 & 3.6567 & 0.72931 \\
\hline 28) When I am faced with a challenge, I give up because I believe I will fail. & 1.00 & 5.00 & 2.5373 & 1.40700 \\
\hline 29) I know what other people are feeling just by looking at them. & 1.00 & 5.00 & 3.4627 & 0.95867 \\
\hline 30) I help other people feel better when they are down. & 1.00 & 5.00 & 4.0746 & 0.78458 \\
\hline 31) I can tell how people are feeling by listening to the tone of their voice. & 2.00 & 5.00 & 3.9254 & 0.58552 \\
\hline 32) I use good moods to help myself keep trying in the face of obstacles. & 2.00 & 5.00 & 3.9851 & 0.63943 \\
\hline 33) It is difficult for me to understand why people feel the way they do. & 1.00 & 5.00 & 2.9851 & 0.91275 \\
\hline Overall Mean score of Emotional intelligence section & 2.18 & 4.64 & 3.7897 & 0.39651 \\
\hline
\end{tabular}


Table 3. Descriptive statistics of readiness for change $(N=67)$.

\begin{tabular}{|c|c|c|c|c|}
\hline Phrases & Min & Max & Mean & Std. Dev \\
\hline 1) My willingness to work more because of change is & 2.00 & 7.00 & 5.6119 & 1.21799 \\
\hline 2) My willingness to solve my organization problems & 2.00 & 7.00 & 5.9104 & 1.25204 \\
\hline 3) My willingness to be a part of the new project is & 2.00 & 7.00 & 5.8806 & 1.32027 \\
\hline 4. My willingness to create new ideas is & 3.00 & 7.00 & 5.9552 & 1.28432 \\
\hline 5) My willingness to make the change fail is & 1.00 & 7.00 & 3.2836 & 2.04351 \\
\hline 6) My willingness to do things in a new or creative way is & 1.00 & 7.00 & 5.7761 & 1.41229 \\
\hline 7) My willingness to change the way I work because of the change is & 1.00 & 7.00 & 5.6866 & 1.37300 \\
\hline 8) My willingness to take responsibility for the change if it fails in my area is & 2.00 & 7.00 & 5.6866 & 1.14427 \\
\hline 9) My willingness to be a part of the change program is & 2.00 & 7.00 & 5.8507 & 1.25835 \\
\hline 10) My willingness to learn new things is & 1.00 & 7.00 & 5.9851 & 1.17412 \\
\hline 11) My willingness to change something even if it appears to be working is & 3.00 & 7.00 & 5.4776 & 1.23532 \\
\hline 12) My willingness to support change is & 2.00 & 7.00 & 5.9851 & 0.97689 \\
\hline $\begin{array}{l}\text { 13) My willingness to improve what we are currently doing rather than implement a } \\
\text { major change is }\end{array}$ & 1.00 & 7.00 & 5.9403 & 1.13992 \\
\hline 14) My willingness to sell ideas about the change is & 1.00 & 7.00 & 5.4179 & 1.48884 \\
\hline Overall Mean Score of Readiness for change & 3.00 & 7.00 & 5.6034 & 0.78486 \\
\hline
\end{tabular}

Table 4. Association between levels of study dimensions.

\begin{tabular}{cccc}
\hline \multirow{2}{*}{$\begin{array}{c}\text { Readiness for } \\
\text { change }\end{array}$} & Low & Emotional intelligence & \\
\cline { 2 - 4 } & $9(13.4 \%)$ & $2(3.0 \%)$ & $\begin{array}{c}\text { Spearman's rho } \\
(\text { P-value })\end{array}$ \\
\hline Low & $38(56.7 \%)$ & $18(26.9 \%)$ & 0.330 \\
High & & $\left.0.006^{* *}\right)$ \\
\hline
\end{tabular}

**: P-value significant at level 0.05 or less.

Table 5. Regression coefficient results.

\begin{tabular}{ccccc}
\hline \multirow{2}{*}{ Table Head } & \multicolumn{4}{c}{ Unstandardized Coefficients } \\
\cline { 2 - 5 } & $\mathrm{B}$ & Std. Error & $\mathrm{T}$ & Sig. \\
\hline (Constant) & 2.934 & 0.874 & 3.356 & 0.001 \\
Emotional intelligence & 0.704 & 0.229 & 3.070 & 0.003 \\
\hline
\end{tabular}

with master's degree had high level with $55.2 \%$ of the total sample. However, there was no association between other demographic variables and RFC or EI $(\mathrm{P}>0.05)$ (Table 6).

\section{Discussion}

The main purpose of this study was to examine the effect of EI on RFC. Additionally, the study sought to explore the association between EI, RFC and 
Table 6. Chi-square results.

\begin{tabular}{|c|c|c|c|c|c|}
\hline \multicolumn{3}{|c|}{ Demographics Characteristics } & \multirow{2}{*}{$\begin{array}{c}\begin{array}{c}\text { Low } \\
(\%)\end{array} \\
7.5\end{array}$} & \multirow{2}{*}{$\begin{array}{c}\text { High } \\
(\%)\end{array}$} & \multirow{2}{*}{$\begin{array}{c}\text { P-value } \\
0.157\end{array}$} \\
\hline & Gender & Male & & & \\
\hline & & Female & 9 & 26.8 & \\
\hline & Education & Bachelor's & 10.4 & 28.4 & \\
\hline & & Master's or above & 6 & 55.2 & 0.070 \\
\hline \multirow[t]{5}{*}{ Readiness for change } & Experience & 5 years or less & 1.5 & 17.9 & \\
\hline & & $6-10$ years & 3 & 17.9 & \\
\hline & & $11-15$ years & 3 & 19.4 & 0.460 \\
\hline & & $16-20$ years & 1.5 & 11.9 & \\
\hline & & 20 years and above & 7.5 & 16.4 & \\
\hline
\end{tabular}

*: P-value significant at level 0.05 .

demographic variables. The findings confirmed the significant relationship between EI and employees' readiness to accept change. This result is in conformity with the previous research, as in the study conducted by [9] to examine the relationships of EI, organizational commitment, and leadership behavior as influences on organization RFC in a higher education institution and concluded that RFC was affected by EI, organizational commitment and transactional leadership behavior. Moreover, the result was consistent with the research done by [31] that confirmed the strong relationship between emotional intelligence and organizational readiness for change. Additionally, the findings of this study support the results of a recent study conducted by [28] who examined the effects of leadership behavior and EI on RFC among employees in public institutions of higher education in Malaysia. The results found that EI had a significant effect on employees' RFC.

This study has several practical implications for organizations going through organizational change. Firstly, it is essential for managers and leaders in different organizations to assess employees' readiness for change to make sure that they are ready for the challenges associated with change. Secondly, managers can design programs to promote employees' emotional intelligence competencies. Enhancing emotional intelligence especially interpersonal and intrapersonal skills will contribute immensely in promoting healthy work relationships and allow more cooperation and support among employees.

Finally, although this study offers insights about the research problem, there were noticeable limitations to this study. This study adopted a cross sectional design where the data were collected at a single point in time. The study utilized self-reporting scales for all variables and this method can have biases and limitations. Future research is recommended to extend the examination of the impact of EI on organizational readiness for change at the individual level, to include work teams as the basic structural unit. Further research may validate this study with larger sample sizes and prove that there is a relationship between EI and 
RFC. Research could also be conducted to understand other dimensions of EI that have more influence on readiness. In addition, future research may initiate a longitudinal study to discover the relationship between EI and employees' readiness for organizational change.

\section{Conflicts of Interest}

The author declares no conflicts of interest regarding the publication of this paper.

\section{References}

[1] Self, D.R. and Schraeder, M. (2009) Enhancing the Success of Organizational Change: Matching Readiness Strategies with Sources of Resistance. Leadership \& Organization Development Journal, 30, 167-182. https://doi.org/10.1108/01437730910935765

[2] Armenakis, A.A., Harris, S.G. and Mossholder, K.W. (1993) Creating Readiness for Organizational Change. Human Relations, 46, 681-703. https://doi.org/10.1177/001872679304600601

[3] Alban, B. (1987) Organizational Transitions: Managing Complex Change.

[4] Cummings, T.G. and Worley, C.G. (2014) Organization Development and Change. Cengage Learning, Boston, MA.

[5] Eby, L.T., Adams, D.M., Russell, J.E. and Gaby, S.H. (2000) Perceptions of Organizational Readiness for Change: Factors Related to Employees' Reactions to the Implementation of Team-Based Selling. Human Relations, 53, 419-442. https://doi.org/10.1177/0018726700533006

[6] Javidan, M., Dorfman, P.W. and Gupta, V. (2004) Culture, Leadership, and Organizations: The GLOBE Study of 62 Societies. Sage, Thousand Oaks, CA, 29-48.

[7] Goleman, D. (1996) Emotional Intelligence. Why It Can Matter More Than IQ. Learning, 24, 49-50.

[8] Huy, Q.N. (1999) Emotional Capability, Emotional Intelligence, and Radical Change. Academy of Management Review, 24, 325-345. https://doi.org/10.5465/amr.1999.1893939

[9] Nordin, N. (2011) The Influence of Emotional Intelligence, Leadership Behaviour and Organizational Commitment on Organizational Readiness for Change in Higher Learning Institution. Procedia-Social and Behavioral Sciences, 29, 129-138. https://doi.org/10.1016/j.sbspro.2011.11.217

[10] Sharma, T. and Singh, S. (2018) Relationship of Emotional Intelligence with Cultural Intelligence and Change Readiness of Indian Managers in the Service Sector. Journal of Organizational Change Management. https://doi.org/10.1108/JOCM-05-2017-0193

[11] Armenakis, A.A. and Harris, S.G. (2009) Reflections: Our Journey in Organizational Change Research and Practice. Journal of Change Management, 9, 127-142. https://doi.org/10.1080/14697010902879079

[12] Armenakis, A.A. and Bedeian, A.G. (1999) Organizational Change: A Review of Theory and Research in the 1990s. Journal of Management, 25, 293-315. https://doi.org/10.1177/014920639902500303

[13] Kotter, J.P. (1996) Leading Change. Harvard Business School Press, Boston, MA.

[14] Self, D.R. (2007) Organizational Change-Overcoming Resistance by Creating Rea- 
diness. Development and Learning in Organizations: An International Journal, 21, 11-13. https://doi.org/10.1108/14777280710779427

[15] Jones, R.A., Jimmieson, N.L. and Griffiths, A. (2005) The Impact of Organizational Culture and Reshaping Capabilities on Change Implementation Success: The Mediating Role of Readiness for Change. Journal of Management Studies, 42, 361-386. https://doi.org/10.1111/j.1467-6486.2005.00500.x

[16] Holt, D.T., Armenakis, A.A., Feild, H.S. and Harris, S.G. (2007) Readiness for Organizational Change: The Systematic Development of a Scale. The Journal of Applied Behavioral Science, 43, 232-255. https://doi.org/10.1177/0021886306295295

[17] Jansen, K.J. (2000) The Emerging Dynamics of Change: Resistance, Readiness, and Momentum. People and Strategy, 23, 53.

[18] Bernerth, J. (2004) Expanding Our Understanding of the Change Message. Human Resource Development Review, 3, 36-52. https://doi.org/10.1177/1534484303261230

[19] Schein, E.H. (1999) Process Consultation Revisited: Building the Helping Relationship. Addison-Wesley, Reading, MA.

[20] Hanpachern, C. (1997) The Extension of the Theory of Margin: A Framework for Assessing Readiness for Change. Doctoral Dissertation, Colorado State University, Fort Collins, CO.

[21] Thorndike, E.L. (1920) Intelligence and Its Uses. Harper's Magazine.

[22] Salovey, P. and Mayer, J.D. (1990) Emotional Intelligence. Imagination, Cognition and Personality, 9, 185-211. https://doi.org/10.2190/DUGG-P24E-52WK-6CDG

[23] Goleman, D. (1998) Working with Emotional Intelligence. Bantam.

[24] Mayer, J.D., Salovey, P., Salovey, P. and Sluyter, D. (1997) Emotional Development and Emotional Intelligence: Implications for Educators. What Is Emotional Intelligence, 3-31.

[25] Dulewicz, V. and Higgs, M. (2000) Emotional Intelligence-A Review and Evaluation Study. Journal of Managerial Psychology, 15, 341-372. https://doi.org/10.1108/02683940010330993

[26] Freshman, B. and Rubino, L. (2002) Emotional Intelligence: A Core Competency for Health Care Administrators. The Health Care Manager, 20, 1-9. https://doi.org/10.1097/00126450-200206000-00002

[27] George, J.M. (2000) Emotions and Leadership: The Role of Emotional Intelligence. Human Relations, 53, 1027-1055. https://doi.org/10.1177/0018726700538001

[28] Gelaidan, H.M., Al-Swidi, A. and Mabkhot, H.A. (2018) Employee Readiness for Change in Public Higher Education Institutions: Examining the Joint Effect of Leadership Behavior and Emotional Intelligence. International Journal of Public Administration, 41, 150-158. https://doi.org/10.1080/01900692.2016.1255962

[29] Schutte, N.S., Malouff, J.M., Hall, L.E., Haggerty, D.J., Cooper, J.T., Golden, C.J. and Dornheim, L. (1998) Development and Validation of a Measure of Emotional Intelligence. Personality and Individual Differences, 25, 167-177. https://doi.org/10.1016/S0191-8869(98)00001-4

[30] Black, W.C., Babin, B.J. and Anderson, R.E. (2010) Multivariate Data Analysis: A Global Perspective. Pearson, London.

[31] Vakola, M., Tsaousis, I. and Nikolaou, I. (2004) The Role of Emotional Intelligence and Personality Variables on Attitudes toward Organisational Change. Journal of Managerial Psychology, 19, 88-110. https://doi.org/10.1108/02683940410526082 